\title{
Entomologica Fennica - a new journal replacing earlier international Finnish entomological journals
}

In 1989 the Academy of Finland decided that from 1990 on, only one Finnish entomological journal in congress languages will be supported. This decision led to the discontinuation of three formerly well-known journals: Acta Entomologica Fennica, Annales Entomologici Fennici, and Notulae Entomologicae. From now on, Finnish entomological monographs will be directed to Acta Zoologica Fennica and shorter articles to a new journal, Entomologica Fennica. The new journal will be edited by the Finnish Zoological Publishing Board whose editorial office prepares the articles ready for offset printing.

Entomologica Fennica will be published quarterly. The journal will publish principally Finnish entomological investigations, i.e. articles written or co-authored by Finns, or articles on material at least some of which is deposited in Finnish collections or is collected from Finland or adjacent geographic areas. Other manuscripts are considered only if they concern the boreal region or if they have ties to Finnish entomology.

The new journal will be published basically within the profile of the former Annales Entomologici Fennici, but as it also replaces Notulae Entomologicae, certain differences will appear. The language of the journal is principally English, with occasional papers in German (with English abstract). A section of short communications, mainly on faunistic novelties from Fennoscandia, is planned to be included once or twice a year.

Entomologica Fennica is intended to cover the whole field of entomology, but from earlier experience it can be assumed that more than half of the text will deal with taxonomy and faunistics, while ecology, ethology, applied entomology and so forth will have a minor part in the journal. Book reviews and congress notifications will also be published.

To guarantee the scientific standard of the journal, all articles will be evaluated by at least two referees. Contributors are kindly asked to prepare their manuscripts according to "Instructions for Authors" (published on the inside of the back cover of every uneven number of each volume).

With these words I open this new forum for internationally aimed Finnish entomology, hoping that the new journal will be appreciated by entomologists all over the world.

Antti Jansson Editor in Chief 